\title{
Performance of the Minievaporimeter UFV-1 to estimate the reference evapotranspiration in relation to the constant groundwater Table lysimeter
}

\author{
Desempeño del Minievaporímetro UFV-1 para estimar \\ la evapotranspiración de referencia con relación al lisímetro \\ de manto freático constante \\ Cristiano Tagliaferre ${ }^{1 *}$, Rubens Alves de Oliveira ${ }^{2}$, Gilberto Chohako Sediyama ${ }^{2}$, \\ Paulo Roberto Cecon², Mauro Aparecido Martinez $z^{2} \&$ Franklin José Valbuena Materán $^{3}$
}

\begin{abstract}
In this work the aim was to evaluate the performance of the minievaporimeter UFV-1, operating with water at a $30 \mathrm{~mm}$ border level, to estimate $\left(\mathrm{ET}_{0}\right)$ in relation to the lysimeter with constant groundwater table. The minievaporimeter UFV-1 is made of PVC and consists of a tube with internal diameter of $244 \mathrm{~mm}$ and $320 \mathrm{~mm}$ height. The minievaporimeters and the lysimeters with constant groundwater Table were separately connected to a modified irrigation meter, which was used to keep water at constant level in its interior and measure the amount of evaporated and evapotranspired depth. The evaporation was related to the (ET $)_{0}$ obtained by the lysimeter to obtain minievaporimeter coefficients. In all the analyzed periods of time, the minievaporimeter presented better $\mathrm{ET}_{0}$ estimate than the other methods studied. These results justify the use of minievaporimeter for irrigation water management.

Key words: evaporation, evaporimeter, irrigation management.
\end{abstract}

\section{RESUMEN}

En este trabajo se ha objetivado evaluar el desempeño del minievaporímetro UFV-1, operando con nivel de agua igual a $30 \mathrm{~mm}$ de la borda, para estimativa de (ETO) en relación al lisímetro del manto freático constante. El minievaporímetro UFV-1 es de PVC y consiste en un tubo con diámetro interno de $244 \mathrm{~mm}$ y altura de $320 \mathrm{~mm}$. Los minievaporímetros y los lisímetros del manto freático constante fueron conectados separadamente a un irrigámetro modificado, lo cual fue utilizado para mantener el nivel de agua constante en su interior y para realizar la lectura de la lámina evaporada y evapotranspirada. La evaporación fue relacionada a la ETO obtenida por el lisímetro para determinar los coeficientes del minievaporímetro. En todos los periodos de tiempo analizados, el minievaporímetro ha presentado mejor estimativa de la ETO que los demás métodos estudiados. Estos resultados justifican el uso del minievaporímetro para manejo del agua de la irrigación.

Palabras clave: evaporación, evaporímetro, manejo de irrigación.

\section{Introduction}

Evapotranspiration is defined as the combination of two distinct processes: the evaporation of the water directly from the ground surface and the perspiration through the plants' stomata (Allen $e t$ al., 2006).

Accurate evapotranspiration estimates are essential to identify the time variations on irrigation needs, to improve the allocation of the water resources, and to evaluate the effect of the use of the land and changes in the management of the water balance (Ortega-Farias et al., 2009).

Jensen (1973) defined reference evapotranspiration (ETr) as the one that occurs in an alfalfa culture (Medicago sativa $\mathrm{L}$.), with 30 to $50 \mathrm{~cm}$ height and minimum buffer area of $100 \mathrm{~m}$, cultivated without water deficiency. Although alfalfa culture has aerodynamic characteristics more representative of agronomic cultures than grass, the later is more used because the great majority of the agro-meteorological stations are grassed. Therefore, Doorenbos \& Pruitt

\footnotetext{
Universidade Estadual Sudoeste da Bahia, Vitória da Conquista-BA, E-mail: tagliaferre@ yahoo.com.br

Universidade Federal de Viçosa, Viçosa-MG.

Universidad del Zulia, Venezuela, Maracaibo.

Autor para correspondencia.
}

Fecha de Recepción: 21 Febrero, 2012.

Fecha de Aceptación: 06 Noviembre, 2012. 
(1977) define $\mathrm{ET}_{0}$ as the evapotranspiration rate of an extensive grass surface with 8 the $15 \mathrm{~cm}$ of height, with active and uniform growth, completely covering the ground, without water limitation. Allen et al. (2006) define $\mathrm{ET}_{0}$ as the evapotranspiration rate of a reference surface, covered by $0.12 \mathrm{~m}$ high hypothetical grass, surface resistance of 70 s.m $\mathrm{M}^{-1}$ - and albedo of 0.23 uniform height, without water restrictions, growing actively and completely shading the ground.

Evapotranspiration can be obtained by direct or estimate measures of climatic elements, using empirical theoretical models or methods. The direct method is represented by several types of lysimeters, being the most accurate method, and considered standard-tool for the determination of reference evapotranspiration (Bernardo et al., 2006; Amorim, 1998).

There are several empirical models in literature that use meteorological elements data to estimate the reference evapotranspiration. These methods are based on observations and statistical analysis, and are generally adequate for a specific climatic or region condition (Fooladmand \& Ahmadi, 2009; Ahmadi \& Fooladmand, 2008; Gavilán et al., 2006).

Amongst the empirical methods, the PenmanMonteith - FAO 56 method is considered standard to estimate the $\mathrm{ET}_{0}$, because it encompasses the physical parameters that govern the exchange of energy and the aerodynamic and physiological aspects of the culture (Smith, 1991; Allen et al., 1998).

Evaporimeters such as the Class A tank is one of the simplest empirical methods to estimate $\mathrm{ET}_{0}$, for irrigation water management purposes. According to Sediyama (1996), the greater use of this equipment is due to its convenience and low installation and maintenance costs. In accordance with Smith (1991), when well used, this method offers trustworthy results in the determination of reference evapotranspiration. It has the advantage of measuring the evaporation of a water-free surface, associating the integrated effects of solar radiation, wind, temperature and humidity of air.
The aim of this work was to evaluate the performance of minievaporimeters UFV-1 in relation to constant groundwater lysimeter, to obtain its coefficients and the reference evapotranspiration estimate, in periods of one, three, five and seven days, and to compare its performance with drainage lysimeter and the methods of Modified Penman - FAO 24, Radiation - FAO 24, Class A tank and Hargreaves-Samani (1985).

\section{Material and Methods}

This study was carried out at the Unit of Research and Development of the Irrigation Meter at the Department of Agricultural Engineering of Universidade de Viçosa (UFV), in Viçosa, MG, located $20^{\circ} 45^{\prime}$ of South latitude and $42^{\circ} 51^{\prime}$ of West longitude, $651 \mathrm{~m}$ altitude. The daily climate elements were obtained at Estação Climatológica of INMET, located in the Campus of UFV, next to the experimental area. The monthly averages of some climatic elements obtained during the experimental period are found in Table 1.

$\mathrm{ET}_{0}$ was estimated using minievaporimeter UFV-1, the methods of Penman-Monteith - FAO 56, Modified Penman - FAO 24, Radiation - FAO 24, Class A tank, Hargreaves-Samani (1985), drainage lysimeter and constant groundwater lysimeter operating with modified irrigation meter. The method of constant groundwater lysimeter was adopted as standard to evaluate the performance of the other methods.

The irrigation meter is an evapo-pluviometric device used in the management of the irrigation water. It was recently developed at Universidade de Viçosa, which is its patent holder. The device allows measuring the evaporated depth, evotranspired depth and precipitated depth, informing directly the time to irrigate and the time of functioning of an irrigation system or its displacement speed. The irrigation meter can function as evaporimeter or evapotranspirometer, depending on the type of

Table 1. Monthly mean values of average air temperature, average relative humidity of air and average wind speed.

\begin{tabular}{lcccccc}
\hline \multirow{2}{*}{ Meteorological elements } & \multicolumn{9}{c}{ Monthly average } \\
\cline { 2 - 7 } & Jul & Aug & Sept & Oct & Nov & Dec \\
\hline Air temperature $\left({ }^{\circ} \mathrm{C}\right)$ & 16.1 & 17.8 & 19.7 & 21.8 & 20.6 & 20.7 \\
Relative air humidity $(\%)$ & 85.7 & 81.4 & 80.0 & 74.3 & 85.3 & 84.0 \\
Wind speed $\left(\mathrm{m} \mathrm{s}^{-1}\right)$ & 0.75 & 0.84 & 1.18 & 1.14 & 0.94 & 0.97 \\
\hline
\end{tabular}


reservoir to which it is connected. In this study, the irrigation meter was modified to meet the needs of this research. Studies with the irrigation meter were carried out by Oliveira et al. (2008), Oliveira \& Tagliaferre (2006), Oliveira \& Ramos (2008) and Tagliaferre et al. (2010).

Three drainage lysimeters and three constant groundwater lysimeters were used at the Unit of Research and Development of Irrigation Meter. The lysimeters were kept at $15 \mathrm{~cm}$ depth and cultivated with Bahia grass (Paspalum notatum L.). Constant groundwater lysimeters were built with $1000 \mathrm{~L}$ asbestos cement box ( $1.10 \mathrm{~m}$ width, $1.60 \mathrm{~m}$ length and $0.70 \mathrm{~m}$ depth), filled with sand substratum, with granules smaller than $1.0 \mathrm{~mm}$ and larger than $0.104 \mathrm{~mm}$, and fed with nutritional solution. Drainage lysimeters were filled with a layer of crushed stones, overlapped by another layer of sand, followed by ground and sieved soil from a red-yellow latosol.

The Bahia grass plantations were trimmed to $8 \mathrm{~cm}$ high each time it reached $15 \mathrm{~cm}$ high, in accordance with the recommendations made by Allen et al. (1998) to estimate the reference evapotranspiration.

The reference evapotranspiration in drainage lysimeters was calculated by means of the water balance, disregarding the storage variation, according to the equation:

$$
E T=P+I-D
$$

where:

ET - reference evapotranspiration, $\mathrm{mm} \mathrm{d}^{-1}$;

$\mathrm{P}$ - rainfall in lysimeter, $\mathrm{mm}$;

I - water depth applied for irrigation, $\mathrm{mm}$; and

$\mathrm{D}$ - drained water depth, mm.

In drainage lysimeters, the irrigations and the collection of the percolated water was made each 24 hours.

Figure 1 shows the constant groundwater lysimeter operating with modified irrigation meter, used to estimate the reference evapotranspiration.

The bottom of each constant groundwater lysimeter was connected to the modified irrigation meter by means of $20 \mathrm{~mm}$ diameter PVC pipe. The irrigation meter was built with feed pipe of $195 \mathrm{~mm}$ internal diameter and 1.100 high with scale graduated in millimeters. The ratio between the internal areas of the lysimeter and of the feed pipe of the irrigation meter, equal to 56.49, enabled the sensitivity in the reading of the evaporated depth equal to $0.018 \mathrm{~mm}$. Evapotranspiration was obtained by the difference between two consecutive readings in a period of 24 hours. The description and functioning of this type of lysimeter, as well as the concentration of the nutritional solution, are found at Materán et al. (2009).

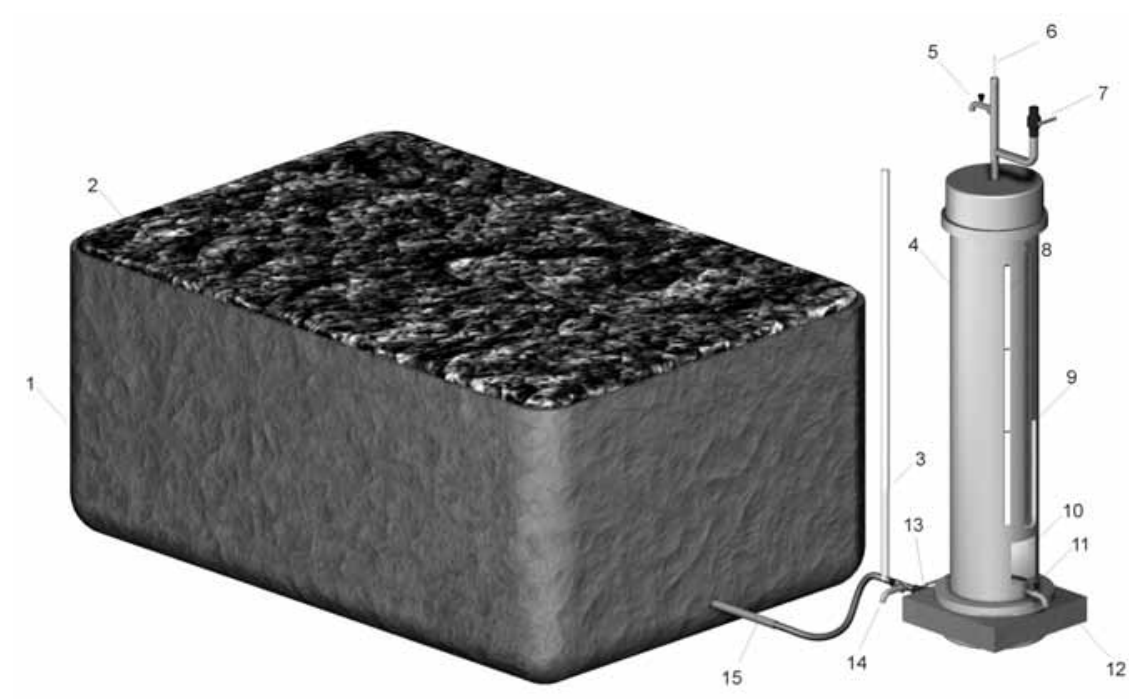

1. Asbestos cement box; 2. Bahia grass plantations; 3. Piezometric pipe; 4. Feed pipe; 5. Air elimination valve; 6. Bubbling pipe; 7. Refueling valve; 8. Reading scale; 9. Piezometer; 10. Display; 11. Drainage valve; 12. Support; 13. Interconnecting valve; 14. Rainwater valve; and 15. Interconnecting pipe.

Figure 1. Constant groundwater lysimeter operating with modified irrigation meter, used to estimate the reference evapotranspiration. 
Figure 2 shows the operating with modified irrigation meter, used to estimate the reference evapotranspiration.

The minievaporimeter UFV-1 (Figure 2) operated as the evaporation pan of a modified irrigation meter, and was composed of a cylindrical PVC container, with external diameter of $250 \mathrm{~mm}$ and internal diameter of $244 \mathrm{~mm}, 320 \mathrm{~mm}$ high, and bottom located $255 \mathrm{~mm}$ from the edge. The minievaporimeter was mounted on a wooden platform $150 \mathrm{~mm}$ high. The description and the functioning of minievaporimeter can be found at Tagliaferre et al. (2006).

The evaporation in the minievaporimeter UFV-1 $\left(\mathrm{Ev}_{\mathrm{ME} 1}\right)$ was obtained in depths of water levels equal to $30,45,60$ and $75 \mathrm{~mm}$ from the edge and kept in constant level by means of the irrigation meter, with three repetitions. In this work, as the performance of the minievaporimeters in the several depths was similar, only the results corresponding to the depth $30 \mathrm{~mm}$ were presented.

The mean coefficient of each type of minievaporimeter $\left(\mathrm{Kt}_{\mathrm{ME}}\right)$ was obtained for each water level, based on the method of constant groundwater lysimeter for determination of reference evapotranspiration $\left(\mathrm{ET}_{0}\right)$, according to the equation.

$$
K t_{M E}=\frac{E T_{0}}{E v_{M E}}
$$

Estimate $\mathrm{ET}_{0}$ with the use of minievaporimeters was obtained by multiplying the daily evaporation value by the mean minievaporimeter coefficient, in each depth. $\mathrm{ET}_{0}$ values of each type of minievaporimeter were later correlated with the valued estimated by the standard method, in the scales of $1,3,5$ and 7 days.

The coefficient of the Class A tank was obtained by means of the application of the equation proposed by Allen \& Pruitt (1991), for tanks surrounded by grass, adopting a grass border equal to $5 \mathrm{~m}$. In the periods of 3, 5 and 7 days, the values of $\mathrm{ET}_{0}$ and the coefficients of the minievaporimeters and the Class A tank were calculated using the mean values of the climate elements. For the drainage lysimeter and the constant groundwater lysimeter, mean $\mathrm{ET}_{0}$ values were used in the period analyzed.

The measurements of evaporation in minievaporimeters and evapotranspiration in drainage lysimeters and constant groundwater were made daily at nine in the morning. In this period, the values of $\mathrm{ET}_{0}$ were also determined by means of the remaining

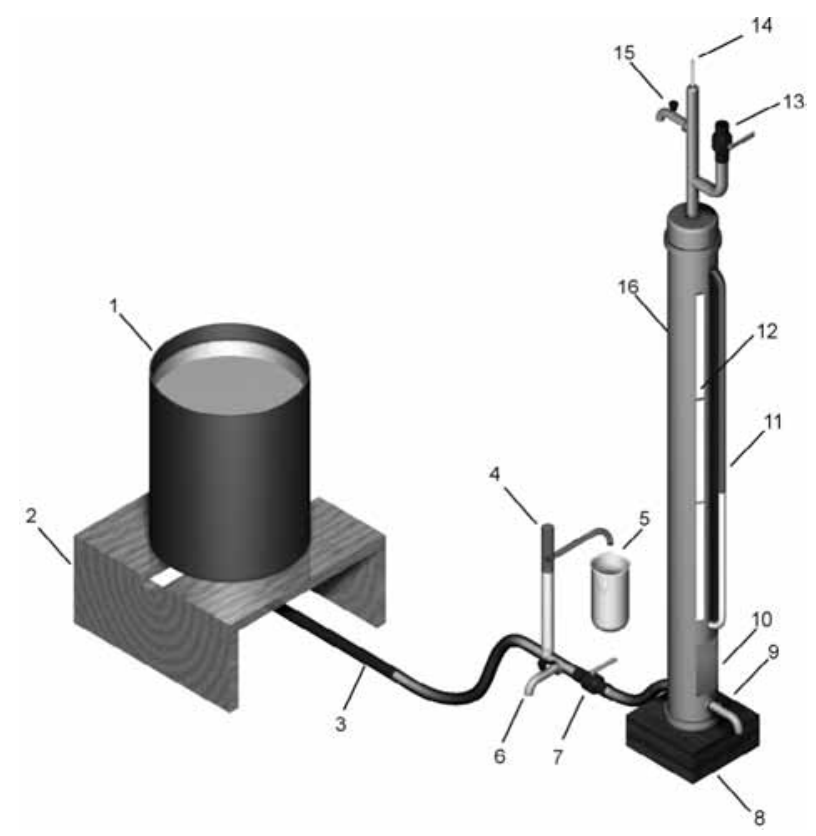

1. Evaporating pan; 2. Platform; 3. Interconnecting pipe; 4. Rainfall pipe; 5. Collector; 6. Rainwater valve; 7. Interconnecting valve; 8. Support; 9. Drainage valve; 10. Display; 11. Piezometer; 12. Reading scale; 13. Refueling valve; 14. Bubbling pipe; 15. Air elimination valve; and 16. Feed pipe.

Figure 2. Minievaporimeter UFV-1 operating with modified irrigation meter, used to estimate the reference evapotranspiration. 
estimate methods studied. Rainy days were excluded from the analysis of the results, because rain affects the reading of evaporated depth and, consequently, the quality of the data.

$\mathrm{ET}_{0}$ values estimated by the methods of PenmanMonteith - FAO 56, Modified Penman, Radiation and Hargreaves-Samani (1985) were obtained with the use of the computer program REF-ET (Allen, 2000).

The analysis of the minievaporimeter UFV-1 performance was made comparing the results of $\mathrm{ET}_{0}$ obtained with the values of $\mathrm{ET}_{0}$ measured in the constant groundwater lysimeter. The methodology adopted for comparison of the results was proposed by Allen $e t$ al. (1986) and adopted by Jensen $e t a l$. (1990), which is based on the (EEP).

The ranking of the evapotranspiration estimates was made based on the values of the (EEP), determination coefficient $\left(\mathrm{r}^{2}\right)$ and the angular coefficient (b) of the respective simple linear regressions.

The accuracy was given by the determination coefficient, which indicates the degree where the regression explains the total square sum. The approach of the $\mathrm{ET}_{0}$ values estimated according to a certain method in relation to the values obtained according to the standard method was obtained by an index, called concurrence or adjustment, represented by the letter "d" (Willmott et al., 1985). Its values vary from zero, where concurrence does not exist, to 1 for perfect concurrence.

The concurrence index is calculated by applying the following equation:

$$
d=1-\frac{\sum_{i=1}^{n}(P i-O i)^{2}}{\sum_{i=1}^{n}[(|P i-\bar{O}|)+(|O i-\bar{O}|)]^{2}}
$$

where:

$\mathrm{d}$ - concurrence of adjustment index;

$\mathrm{P}_{\mathrm{i}}$ - reference evapotranspiration obtained according to the considered method, $\mathrm{mm} \mathrm{d}^{-1}$;

$\mathrm{O}_{\mathrm{i}}$ - reference evapotranspiration obtained according to the standard method, mm d-1;

$\overline{\mathrm{O}}$ - mean $\mathrm{ET}_{0}$ values obtained according to the standard method, $\mathrm{mm} \mathrm{d}^{-1}$; and

$\mathrm{n}$ - number of observations.

\section{Results and Discussion}

According to the results presented in Table 1, it is observed that the mean relative humidity was higher than $70 \%$, classified as high, and the mean temperature was close to $20^{\circ} \mathrm{C}$. The mean wind speed was lower than $2 \mathrm{~m} \mathrm{~s}^{-1}$, considered light, according to Doorenbos \& Pruitt (1977). The climatic conditions, represented by the relative humidity and wind speed allowed determining only one coefficient to the minievaporimeter, in each time interval analyzed, as can be observed in Table 2 .

Table 2. Values of the coefficients of minievaporimeter UFV-1 obtained for each analyzed time interval.

\begin{tabular}{cccccc}
\hline & & \multicolumn{4}{c}{ Studied time Interval (days) } \\
\hline UR (\%) & Vv $\left(\mathrm{m} \mathrm{s}^{-1}\right)$ & One & Three & Five & Seven \\
High $>70$ & 2.0 (light) & 0.47 & 0.47 & 0.47 & 0.47 \\
\hline
\end{tabular}

$\mathrm{UR}=$ Relative Humidity; $\mathrm{Vv}=$ Wind speed.

With regard to the studied time interval, it was observed that coefficient values of the minievaporimeter remained constant. Thus, the use of the value of 0.47 for all studied time intervals is recommended.

Table 3 presents the parameters of the regression equation $(a, b)$, the determination coefficient $\left(r^{2}\right)$,

Table 3. Parameters of the regression equation $(a, b)$, determination coefficient $(r 2)$, (EEP), concurrence index (d) and values of ET0 (mm d-1) for daily periods.

\begin{tabular}{|c|c|c|c|c|c|c|}
\hline Method & Method & Method & $r^{2}$ & EEP & EEP & $\mathrm{ET}_{0}$ \\
\hline Constant Groundwater Lysimeter & - & - & - & - & - & 2.80 \\
\hline Modified Penman & -0.300 & 1.224 & 0.82 & 0.71 & 0.91 & 3.12 \\
\hline Hargreaves-Samani & 1.500 & 0.855 & 0.71 & 1.24 & 0.73 & 3.89 \\
\hline Radiation & 0.234 & 1.147 & 0.81 & 0.88 & 0.87 & 3.44 \\
\hline Class A Tank & 0.378 & 0.828 & 0.84 & 0.42 & 0.95 & 2.69 \\
\hline P. - Monteith - FAO 56 & 0.459 & 0.904 & 0.83 & 0.47 & 0.95 & 2.99 \\
\hline Drainage Lysimeter & 0.491 & 0.812 & 0.62 & 0.68 & 0.88 & 2.76 \\
\hline Min. UFV-1, $\mathrm{P}=30 \mathrm{~mm}$ & 0.275 & 0.909 & 0.88 & 0.36 & 0.97 & 2.81 \\
\hline
\end{tabular}


the (EEP) and concurrence index (d), obtained for daily values of $\mathrm{ET}_{0}$ estimated by means of minievaporimeters UFV-1 and UFV-2 and by the remaining methods studied, based on the method of constant groundwater lysimeter.

In Table 3 it is observed that the Modified Penman method, that considers the aerodynamic and radiation aspects, presented good estimate of $\mathrm{ET}_{0}$, with a small overestimate of reference evapotranspiration obtained with the standard method, with of $0.71 \mathrm{~mm} \mathrm{~d}^{-1}$. However, Hargreaves-Samani and Radiation methods overestimated reference evapotranspiration, presenting equal to 1.24 and $0.88 \mathrm{~mm} \mathrm{~d}^{-1}$, respectively. These overestimates corroborate the results found by Jensen et al. (1990) and Mendonça et al. (2003), who worked with weighing lysimeters in Campos dos Goytacazes, Rio de Janeiro. According to Jensen et al. (1990), the methods that are based on radiation and air temperature, as Hargreaves-Samani, tend to overestimate the reference evapotranspiration in 15 to $25 \%$ in humid climates.

The Class A tank and drainage lysimeter presented satisfactory estimate results for daily $\mathrm{ET}_{0}$, with standard error of estimate equal to 0.42 and $0.68 \mathrm{~mm} \mathrm{~d}^{-1}$, respectively, although these are recommended for time intervals higher than seven days to estimate reference evapotranspiration. These two methods presented an underestimation of the daily $\mathrm{ET}_{0}$, in relation to the standard method, equal to 3.9 and $1.4 \%$, respectively.

The Penman-Monteith - FAO 56 method, adopted as world standard in works on $\mathrm{ET}_{0}$, overestimated $\mathrm{ET}_{0}$ obtained in constant groundwater lysimeter in $6.7 \%$, with standard error of estimate equal to $0.47 \mathrm{~mm} \mathrm{~d}^{-1}$. This result indicates that the constant groundwater lysimeter, kept at $15 \mathrm{~cm}$ of depth, in the climatic conditions mentioned in this study, presented excellent result of daily $\mathrm{ET}_{0}$ estimate. The excellent performance of the constant groundwater lysimeter was a result of the good development of the Bahia grass plantations and the high sensitivity of the reading of the evotranspired depth, equal to $0.018 \mathrm{~mm}$, becoming necessary equipment.

The small underestimate of $\mathrm{ET}_{0}$ obtained in the constant groundwater lysimeter in relation to the Penman-Monteith - FAO 56 method can be related to the frequent cuts of the Bahia grass plantations, made each two weeks to keep its height between 8 and $15 \mathrm{~cm}$, as recommended by Allen et al. (1998), Smith (1991) and Doorenbos \& Pruitt (1977).
These pruning cause plant injuries that affect the evapotranspiration rate in the first subsequent days after the pruning. Allen et al. (1989) mentioned that both the covering and the height of the grass in lysimeters can overestimate or underestimate $\mathrm{ET}_{0}$ for the combined methods.

Minievaporimeter UFV-1 operating with modified irrigation meter presented $\mathrm{ET}_{0}$ estimate very close to that obtained with the method of constant groundwater lysimeter, with standard error of estimate of $0.36 \mathrm{~mm} \mathrm{~d}^{-1}$. The analysis of the values of the angular and determination coefficients, the concurrence index and the standard error of estimate indicated that the minievaporimeter UFV-1 was, amongst the studied methods, the one that better estimated $\mathrm{ET}_{0}$ based on the standard method. Thus, the minievaporimeter operating with modified irrigation meter presented trustworthy results to estimate $\mathrm{ET}_{0}$ in daily periods, which associated to the low cost and high practicality make these devices fit for irrigation water management purposes.

Figure 3 shows the regression equations, determination coefficient and daily values of reference evapotranspiration estimated by the studied methods and the method of constant groundwater lysimeter.

The methods of Modified Penman, HargreavesSamani and Radiation overestimated $\mathrm{ET}_{0}$ obtained with constant groundwater lysimeter; the opposite behavior occurred with the use of drainage lysimeter and with the Class A tank. It was observed in these methods larger dispersion of $\mathrm{ET}_{0}$ data in relation to the trend line for values higher than $3.5 \mathrm{~mm} \mathrm{~d}^{-1}$.

The method of Penman-Monteith - FAO 56, amongst the studied empirical methods, had the best performance, presenting declivity straight practically equal to 1 , in comparison with the method of constant groundwater lysimeter. Several works indicated good correlation between $\mathrm{ET}_{0}$ data obtained in lysimeters and estimated by the equation of Penman-Monteith - FAO 56; also Allen (1986), Allen et al. (1989), Jensen et al. (1990), Camargo \& Sentelhas (1997) and Hussein (1999) may be mentioned in this regard.

Minievaporimeter UFV-1 presented performance similar to the method of Penman-Monteith - FAO 56 to estimate $\mathrm{ET}_{0}$ in all the evaluated water levels, surpassing the other $\mathrm{ET}_{0}$ estimate methods considered in this study. These methods presented lower $\mathrm{ET}_{0}$ daily data dispersion around the line of 1:1 values, on the basis of the method of constant groundwater lysimeter operating with modified irrigation meter. 

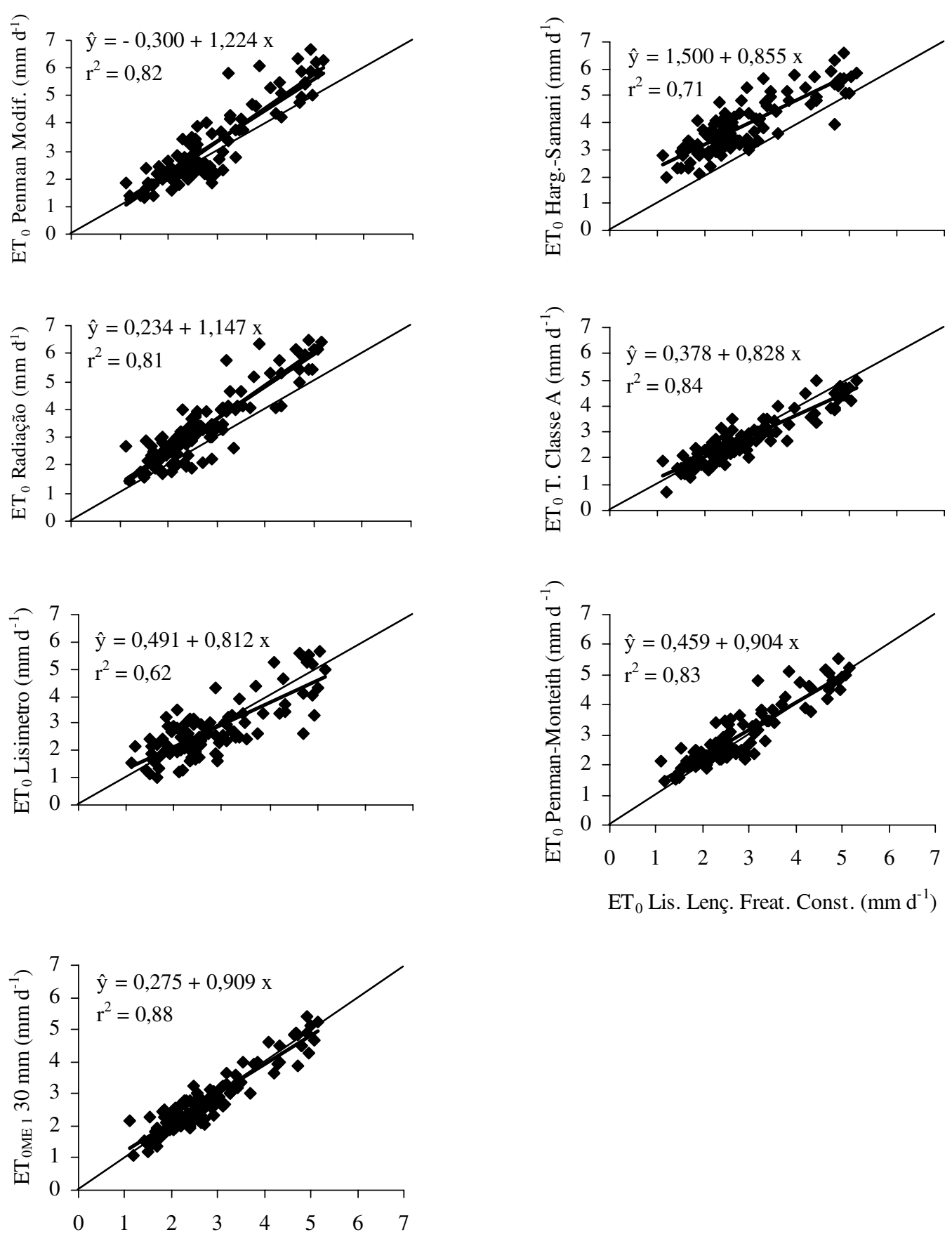

$\mathrm{ET}_{0}$ Lis. Lenç. Freat. Const. $\left(\mathrm{mm} \mathrm{d}^{-1}\right)$

Figure 3. Reference Evapotranspiration ( $\mathrm{ET}_{0}$ ) estimated by the methods Modified Penman, Hargreaves-Samani, Radiation, Class A tank, drainage lysimeter and Penman-Monteith-FAO 56 and by minievaporimeter UFV-1 ( $\left.\mathrm{ET}_{0 \mathrm{ME} 1}\right)$, in comparison with the values of $\mathrm{ET}_{0}$ determined by constant groundwater lysimeter, for daily periods. 
Following the statistical methodology applied in the daily scale, the comparison of the methods in the periods of three, five and seven days were already performed, as presented in Table 4.

It may be observed by analyzing the data on Table 4 that the grouping of $\mathrm{ET}_{0}$ in periods of three, five and seven days, respectively, resulted in the increase of the adjustment and determination coefficients, with values next to the unit; and reduction of the standard error of estimate, with values close to zero in the majority of the studied methods, comparatively to the values obtained in daily periods. This was expected because the grouping of $\mathrm{ET}_{0}$ values in longer period of time improves the performance of the methods, because of the softening of the specific fluctuations of the data.

The method of Penman-Monteith - FAO 56 presented standard error of estimate values in intervals of three, five and seven days, equal to 0.32; 0.29 ; and $0.27 \mathrm{~mm} \mathrm{~d}^{-1}$, respectively, with concurrence index value equal to 0.97 and determination coefficient varying from 0.92 to 0.95 . Thus, the constant groundwater lysimeter operating with modified irrigation meter was fit to estimate $\mathrm{ET}_{0}$ in all the studied time intervals.

In the intervals of three, five and seven days, minievaporimeter UFV-1 presented declivity straight values close to 1 . Minievaporimeter UFV-1 showed standard error of estimate values equal to $0.24,0.28$, and $0.21 \mathrm{~mm} \mathrm{~d}-1$; concurrence index values equal to $0.98,0.98$, and 0.99 ; determination coefficient equal to $0.93,0.95$ and 0.96 , respectively, in the periods of time of three, five and seven days.

These results indicate that the minievaporimeter performed better to estimate $\mathrm{ET}_{0}$ than the other studied methods, as the parameters values of the adjusted regression equations were very close to the ideal condition, i.e., $\mathrm{a}=0$ and $\mathrm{b}=1$, with $\mathrm{ET}_{0}$ estimates practically equal to the method of constant groundwater lysimeter.

Figures 4, 5 and 6 present the regression equations, determination coefficients and $\mathrm{ET}_{0}$ values estimated by the methods studied and measured by the constant groundwater lysimeter, in periods of three, five and seven days, respectively.

Table 4. Parameters of the regression equation $(a, b)$, determination coefficient $\left(r^{2}\right)$, standard error of estimate (EEP), concurrence index $(\mathrm{d})$ and $\mathrm{ET}_{0}$ values $\left(\mathrm{mm} \mathrm{d}^{-1}\right)$ for periods of three, five and seven days.

\begin{tabular}{|c|c|c|c|c|c|c|}
\hline Method & a & $\mathrm{b}$ & $\mathrm{r}^{2}$ & EEP & $\mathrm{d}$ & $\mathrm{ET}_{0}$ \\
\hline \multicolumn{7}{|l|}{ Period of three days } \\
\hline Constant Groundwater Lysimeter & - & - & - & - & - & 2.79 \\
\hline Modified Penman & -0.527 & 1.301 & 0.91 & 0.56 & 0.93 & 3.11 \\
\hline Hargreaves-Samani & 1.163 & 0.982 & 0.85 & 1.19 & 0.72 & 3.91 \\
\hline Radiation & 0.275 & 1.128 & 0.89 & 0.74 & 0.87 & 3.43 \\
\hline Class A Tank & 0.411 & 0.833 & 0.86 & 0.34 & 0.96 & 2.74 \\
\hline P. - Monteith - FAO 56 & 0.283 & 0.964 & 0.92 & 0.32 & 0.97 & 2.98 \\
\hline Percolation lysimeter & -0.104 & 1.024 & 0.82 & 0.43 & 0.95 & 2.76 \\
\hline Min. UFV-1, $\mathrm{P}=30 \mathrm{~mm}$ & 0.304 & 0.888 & 0.93 & 0.24 & 0.98 & 2.78 \\
\hline \multicolumn{7}{|l|}{ Period of five days } \\
\hline Constant Groundwater Lysimeter & - & - & - & - & - & 2.79 \\
\hline Modified Penman & -0.533 & 1.311 & 0.93 & 0.53 & 0.93 & 3.12 \\
\hline Hargreaves-Samani & 1.187 & 0.979 & 0.85 & 1.21 & 0.71 & 3.92 \\
\hline Radiation & 0.306 & 1.119 & 0.94 & 0.71 & 0.88 & 3.43 \\
\hline Class A Tank & 0.331 & 0.861 & 0.91 & 0.28 & 0.97 & 2.75 \\
\hline P. - Monteith - FAO 56 & 0.272 & 0.972 & 0.94 & 0.27 & 0.97 & 2.98 \\
\hline Percolation lysimeter & 0.056 & 1.011 & 0.82 & 0.41 & 0.95 & 2.77 \\
\hline Min. UFV-1, $\mathrm{P}=30 \mathrm{~mm}$ & 0.289 & 0.893 & 0.95 & 0.21 & 0.98 & 2.78 \\
\hline \multicolumn{7}{|l|}{ Period of three days } \\
\hline Constant Groundwater Lysimeter & - & - & - & - & - & 2.80 \\
\hline Modified Penman & -0.670 & 1.354 & 0.95 & 0.51 & 0.93 & 3.12 \\
\hline Hargreaves-Samani & 0.890 & 1.084 & 0.90 & 1.20 & 0.70 & 3.92 \\
\hline Radiation & 0.280 & 1.123 & 0.95 & 0.70 & 0.86 & 3.42 \\
\hline Class A Tank & 0.465 & 0.818 & 0.92 & 0.25 & 0.97 & 2.75 \\
\hline P. - Monteith - FAO 56 & 0.178 & 1.003 & 0.95 & 0.27 & 0.97 & 2.98 \\
\hline Percolation lysimeter & -0.498 & 1.166 & 0.97 & 0.22 & 0.98 & 2.76 \\
\hline Min. UFV-1, $\mathrm{P}=30 \mathrm{~mm}$ & 0.298 & 0.889 & 0.96 & 0.18 & 0.99 & 2.79 \\
\hline
\end{tabular}



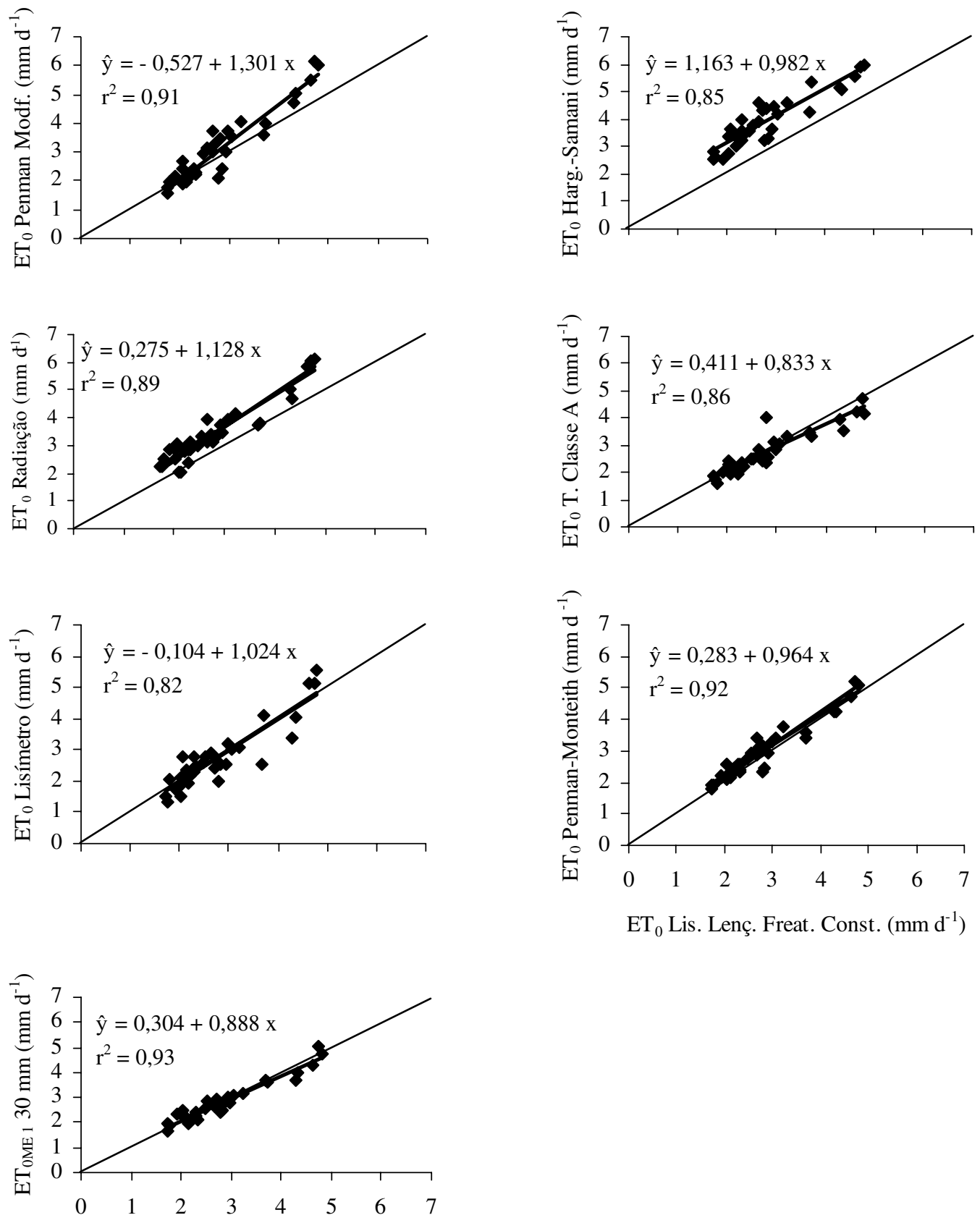

$\mathrm{ET}_{0}$ Lis. Lenç. Freat. Const. $\left(\mathrm{mm} \mathrm{d}^{-1}\right)$

\section{$\mathrm{ET}_{0}$ Lis. Lenç. Freat. Const. $\left(\mathrm{mm} \mathrm{d}^{-1}\right)$}

Figure 4. Reference Evapotranspiration ( $\mathrm{ET}_{0}$ ) estimated by the methods Modified Penman, Hargreaves-Samani, Radiation, Class A tank, drainage lysimeter and Penman-Monteith - FAO 56 and by minievaporimeter UFV-1 (ET $\left.{ }_{0 \mathrm{ME1}}\right)$, in comparison with the values of $\mathrm{ET}_{0}$ determined by constant groundwater lysimeter, for periods of three days. 

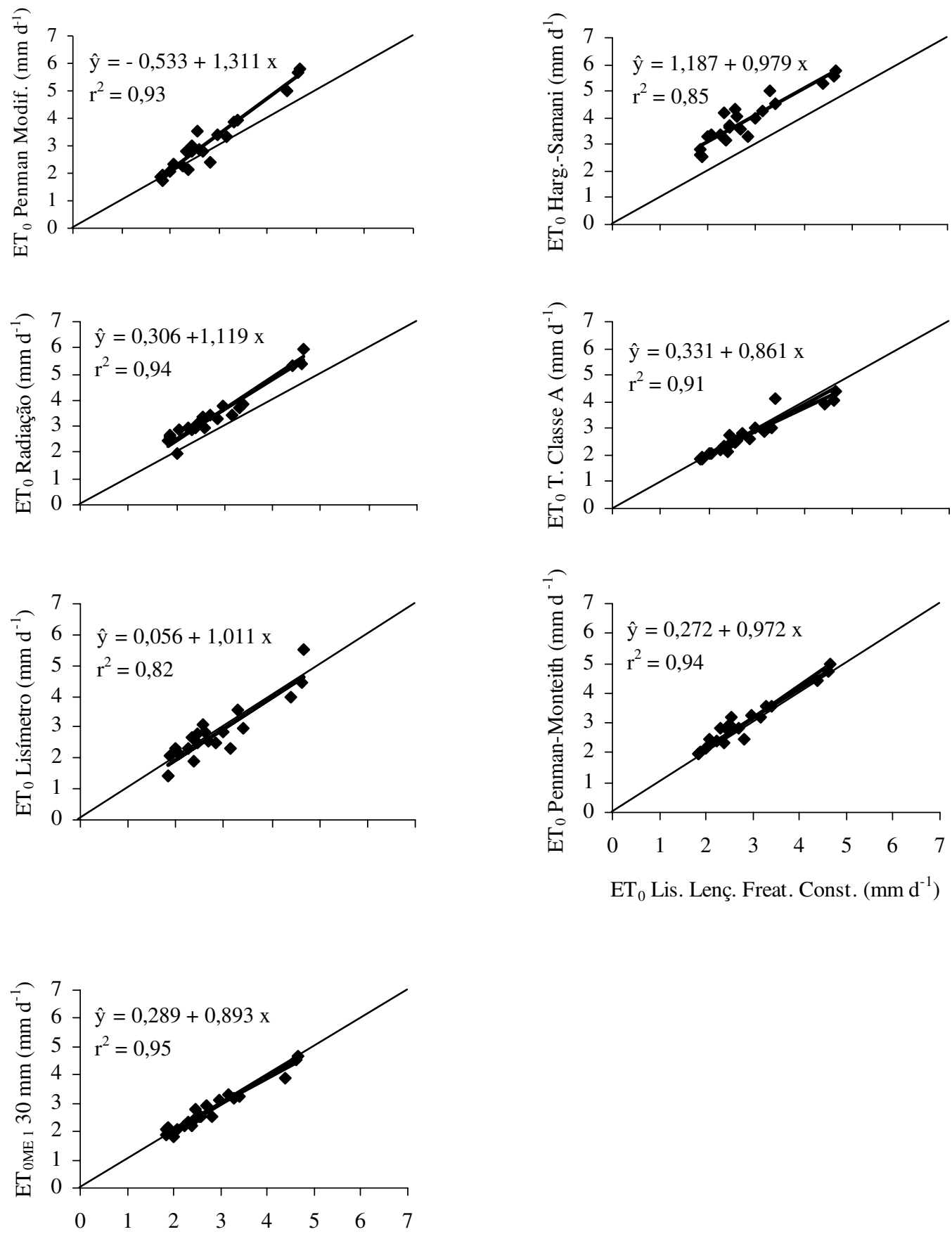

$\mathrm{ET}_{0}$ Lis. Lenç. Freat. Const. $\left(\mathrm{mm} \mathrm{d}^{-1}\right)$

Figure 5. Reference Evapotranspiration (ET0) estimated by the methods Modified Penman, Hargreaves-Samani, Radiation, Class A tank, drainage lysimeter and Penman-Monteith - FAO 56 and by minievaporimeter UFV-1 $\left(\mathrm{ET}_{0 \mathrm{ME} 1}\right)$, in comparison with the $\mathrm{ET}_{0}$ values determined by constant groundwater lysimeter, for periods of five days. 

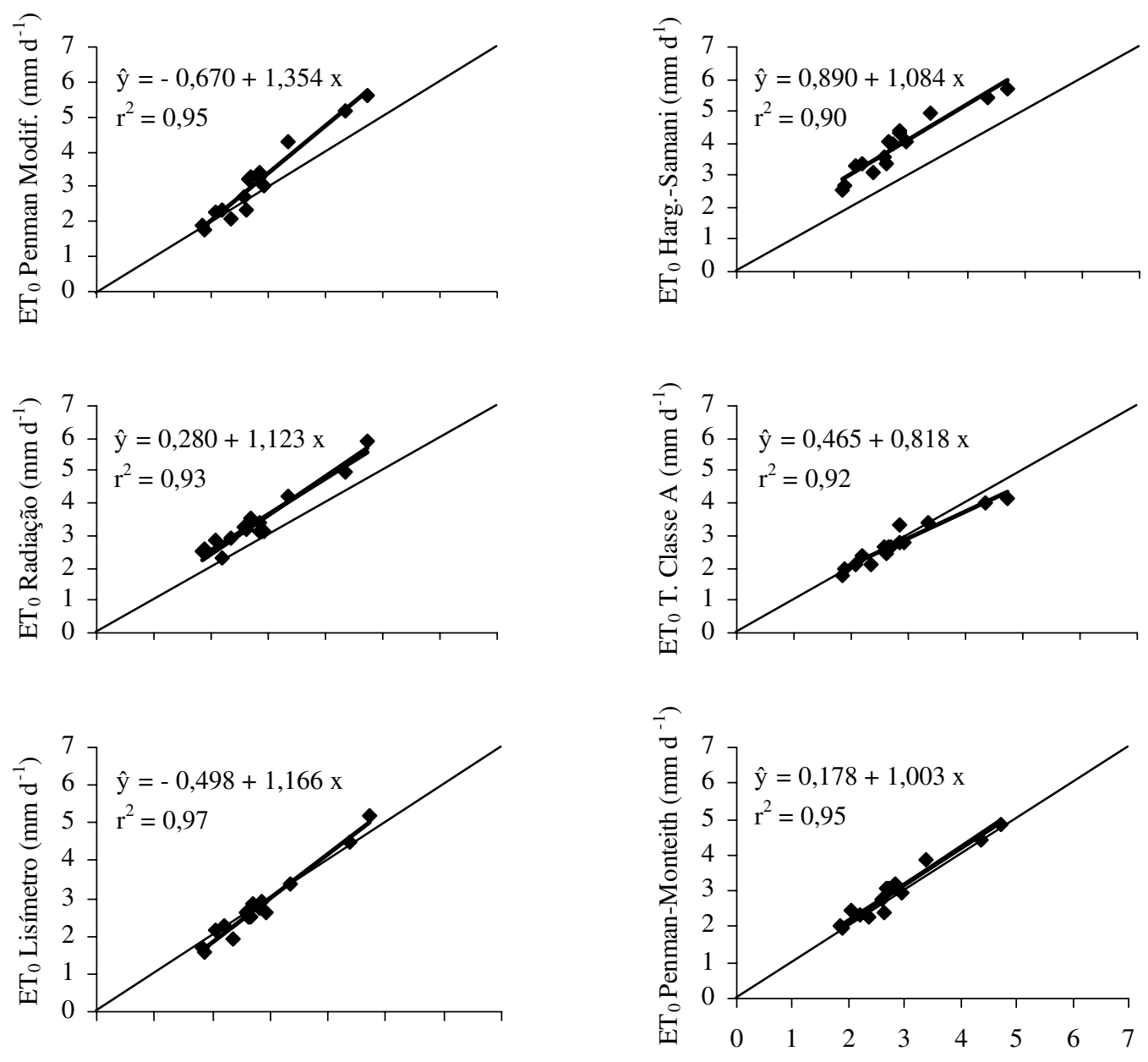

$\mathrm{ET}_{0}$ Lis. Lenç. Freat. Const. $\left(\mathrm{mm} \mathrm{d}^{-1}\right)$

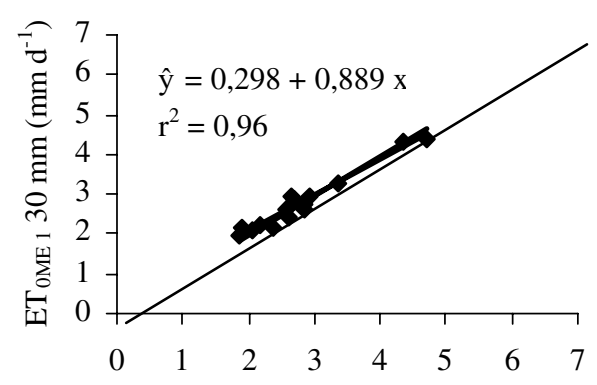

$\mathrm{ET}_{0}$ Lis. Lenç. Freat. Const. $\left(\mathrm{mm} \mathrm{d}^{-1}\right)$

Figure 6. Reference Evapotranspiration (ET0) estimated by the methods Modified Penman, Hargreaves-Samani, Radiation, Class A tank, drainage lysimeter and Penman-Monteith - FAO 56 and by minievaporimeter UFV-1 $\left(\mathrm{ET}_{0 \mathrm{ME1}}\right)$, in comparison with the ET0 values determined by constant groundwater lysimeter, for periods of seven days. 
In the analysis of Figures 4, 5 and 6 it was observed that the grouping of data in larger periods tends to improve $\mathrm{ET}_{0}$ estimate; the same behavior was observed for the methods of Modified Penman, Hargreaves-Samani and Radiation, that overestimated and drainage lysimeter and Class A tank lightly that underestimated, comparatively to the method of constant groundwater lysimeter.

The drainage lysimeter and the Class A tank presented significant improvement in the estimate of $\mathrm{ET}_{0}$ in periods of three, five and seven days, comparatively to the values obtained in the daily periods, with lesser standard error estimates and greater concurrence index, justifying its use with more accuracy in the determination of the water consumption for a culture in time period longer than seven days, as recommended by Jensen $e t$ al. (1990) and Doorenbos \& Pruitt (1977).

In the periods of three, five and seven days, the mean reference evapotranspiration values obtained in the minievaporimeter UFV-1 was practically equal to the mean $\mathrm{ET}_{0}$ obtained with the method of constant groundwater lysimeter. It is important to emphasize that the excellent performance of minievaporimeters is conditioned to the use of the modified irrigation meter, which allowed obtaining evaporated depth measures with sensitivity of $0.086 \mathrm{~mm}$. Similar results were also obtained by Tagliaferre et al. (2006) when comparing the performance of minievaporimeter UFV-1 to the method of Penman-Monteith-FAO 56.

\section{Conclusions}

1. Minievaporimeter UFV-1 operating with modified irrigation meter presented adequate performance, comparatively to the method of constant groundwater lysimeter, to estimate $\mathrm{ET}_{0}$ in all the studied periods of time.

2. The methods of Modified Penman, Hargreaves-Samani and Radiation overestimated the $\mathrm{ET}_{0}$ obtained with the method of constant groundwater lysimeter in all the studied intervals of time, while drainage lysimeter and Class A tank underestimated it.

3. The method of Penman-Monteith FAO 56 presented a light overestimate of the $\mathrm{ET}_{0}$ obtained with the method of constant groundwater lysimeter, with an excellent performance in the estimate of $\mathrm{ET}_{0}$.

\section{Acknowledgements}

The authors thank Conselho Nacional de Desenvolvimento Científico e Tecnológico (CNPq) and Coordenação de Aperfeiçoamento de Pessoal de Nível Superior (CAPES) for the financial aid.

\section{References}

Ahmadi, S.H.; Fooladmand, H.R.

2008 Spatially distributed monthly reference evapotranspiration derived from the calibration of Thornthwaite equation: a case study, South of Iran. Irrigation Science, v.26 (4): 303-312.

Allen, R.G.

1986 A Penman for all seasons. Journal of Irrigation and Drainage Engineering, v.112 (4): 348-386.

Allen, R.G.; Pereira, L.S.; Raes, D.; Smith, J.

2006 Evapotranspiracion del cultivo: guias para la determinación de los requerimientos de agua de los cultivos cultivos. FAO, 298p. (Estudio Riego e Drenaje Paper, 56).

Allen, R.G.; Jensen, M.E.; Wright, J.L.; Burman, R.D.

1989 Operational estimates of reference evapotranspiration. Agronomy Journal, v.81: 650-662.

Allen, R.G.; Pereira, L.S.; Raes, D.; Smith, M.

1998 Guidelines for computing crop water requirements. FAO, 310 p. (Irrigation and drainage Paper, 56).

Allen, R.G.; Pruitt, W.O.

1991 Reference evapotranspiration factors. Journal of Irrigation and Drainage Engineering, v.117 (5): 758-772.

Allen, R.G.

2000 Ref-Et: reference evapotranspiration calculator, Version 2.1. Idaho University, $82 \mathrm{p}$.
Amorim, M.C. de.

1998 Avaliação da eficácia do lisímetro de lençol freático constante, do tanque classe "A" e do modelo de PenmanMonteith (FAO) para estimativa da evapotranspiração de referência $\left(\mathrm{ET}_{0}\right)$. Tese de Mestrado. Universidade Federal de Viçosa, Viçosa. 56 p.

Bernardo, S.; Soares, A.A.; Mantovani, E.C.

2006 Manual de irrigação. 8. ed. Universidade Federal de Viçosa, $625 \mathrm{p}$.

Camargo, A.P.; Sentelhas, P.C.

1997 Avaliação do desempenho de diferentes métodos de estimativa da evapotranspiração potencial no Estado de São Paulo. Revista brasileira de Agrometeorologia, v. 5 (1): 89-97.

Doorenbos, J.; Pruitt, J.O.

1977 Crop water requirement. FAO, 144 p (FAO Irrigation and Drainage Paper 24).

Fooladmand, H.R.; Ahmadi, S.H.

2009 Monthly spatial calibration of Blaney-Criddle equation for calculating monthly ETo in the South of Iran. Irrigation and Drainage Drainage, v. 58 (2): 234-245.

Gavilán, P.; Lorite, I.J.; Tornero, S.; Berengena, J.

2006 Regional calibration of Hargreaves equation for estimating reference ET in a semiarid environment. Agriculture Water Management. Management, v. 81: 257-281. 
Hargreaves, G.H.; Samani, Z.A.

1985 Reference crop evapotranspiration from temperature. Applied Engineering Agriculture, v.1 (2): 96-99.

Hussein, A.S.A.

1999 Grass ET estimates using Penman-type equations in Central Sudan. Journal of irrigation and Drainage Engineering, v. 125 (6): 324-329.

Jensen, M.E.

1973 Consumptive use of water and irrigation water requirements. ASCE, $215 \mathrm{p}$.

Jensen, M.E.; Burman, R.D.; Allen, R.G.

1990 Evapotranspiration and irrigation water requirements. ASCE, $332 \mathrm{p}$.

Materan, F.J.V. Oliveira, R.A. de; Cecon, P.R.; Sediyama, G.C.; Martinez, H.E.P.; Tagliaferre, C.

2009 Lisímetro com lençol freático constante operando com Irrigâmetro ${ }^{\circledR}$ modificado para medida da evapotranspiração de referência. Revista UDO Agrícola, v. 9 (2): 364-375.

Mendonça, J.C.; Souza, E.F. de; Bernardo, S.; Dias, G.P.; Grippa, S. 2003 Comparação entre métodos de estimativa da evapotranspiração de referência $\left(\mathrm{ET}_{0}\right)$ na região Norte Fluminense, RJ. Revista Brasileira de Engenharia Agrícola e Ambiental, v. 7 (2): 275-279.

Oliveira, R.A.; Tagliaferre, C.; Sediyama, G.C.; Materan, F.J.V.; Cecon, P.R.

2008 Desempenho do irrigâmetro na estimativa da evapotranspiração de referência. Revista Brasileira de Engenharia Agrícola e Ambiental, v. 12 (2): 166-173.

Oliveira, R.A. de; Tagliaferre, C.

2006 Irrigâmetro: nova tecnologia para manejo da água de irrigação. In: Barbosa, T.C.; Taniguchi, G.C.; Penteado,
D.C.S.; Silva, D.J.H. da. Ambiente protegido: olericultura, citricultura e floricultura. Ed. UFV: Universidade Federal de Viçosa, 39-64.

Oliveira, R.A.; Ramos, M.M.

2008 Manual do irrigâmetro. Ed. UFV: Universidade Federal de Viçosa, 144 p.

Ortega-Farias, S.; Irmak, S.; Cuenca, R.H.

2009 Special issue on evapotranspiration measurement and modeling, Irrigation Science v. 28 (1): 1-3.

Sediyama, G.C.

1996 Necessidade de água para os cultivos. Brasília: ABEAS, $176 \mathrm{p}$.

Smith, M.

1991 Report on the expert consultation on revision of crop water requirements. FAO, $45 \mathrm{p}$.

Tagliaferre, C.; Oliveira, R.A. de; Sediyama, G.C.; Cecon, P.R.; Deniculi, W.; Martinez, M.A.; Materan, F.J.V.

2006 Estimativa da evapotranspiração de referência usando minievaporimetro operando com irrigâmetro modificado. Engenharia na Agricultura, v. 14 (3): 212-223.

Tagliaferre, C.; Oliveira, R.A. de; Oliveira, E.M. de; Baptestini, J.C.B.; Santos, L. da C.

2010 Desempenho do Irrigâmetro no Manejo da Água de Irrigação na Cultura do Feijoeiro. Revista Caatinga, v. 23 (3): 110-117.

Willmott, C.J.; Ckleson, S.G.; Davis, R.E.

1985 Statistics for evaluation and comparison of models. Journal of Geophysical Research, Ottawa, v. 90, (5): 8995-9005. 
